\title{
A Polychromatic Approach to the Rainbow Nation Today: Bitter Fruit by Achmat Dangor, "Nietverloren" and Disgrace by J.M. Coetzee
}

Madeleine Laurencin

\section{CpenEdition} Journals

Electronic version

URL: https://journals.openedition.org/ces/5488

DOI: $10.4000 /$ ces.5488

ISSN: 2534-6695

Publisher

SEPC (Société d'études des pays du Commonwealth)

\section{Printed version}

Date of publication: 1 April 2012

Number of pages: 51-60

ISSN: 2270-0633

\section{Electronic reference}

Madeleine Laurencin, "A Polychromatic Approach to the Rainbow Nation Today: Bitter Fruit by Achmat Dangor, "Nietverloren" and Disgrace by J.M. Coetzee", Commonwealth Essays and Studies [Online], 34.2 I 2012, Online since 19 April 2021, connection on 23 July 2021. URL: http://journals.openedition.org/ ces/5488 ; DOl: https://doi.org/10.4000/ces.5488

\section{(c) $(7)(8)$}

Commonwealth Essays and Studies is licensed under a Licence Creative Commons Attribution - Pas d'Utilisation Commerciale - Pas de Modification 4.0 International. 


\section{A Polychromatic Approach to the Rainbow Nation Today: Bitter Fruit by Achmat Dangor, "Nietverloren" and Disgrace by J.M. Coetzee}

Achmat Dangor in Bitter Fruit and J. M. Coetzee in both "Nietverloren" and Disgrace reveal aspects of the Rainbow Nation wrestling with questions of Black, White, and Coloured identities, as well as with the difficulty of reconciling the past with the present. These texts of fiction map some of the directions South Africa and its literature are taking today, wondering to what extent the idea of the Rainbow Nation has survived intact, more than fifteen years after the end of apartheid.

In 1994, during his first month of office, Nelson Mandela proclaimed that every South African was "as intimately attached to the soil of this beautiful country as [...] the famous jacaranda trees of Pretoria and the mimosa trees of the bushveld [...] a rainbow nation at peace with itself and the world" ("Inauguration Speech"). Taking up the image originally used by Archbishop Desmond Tutu a few months earlier, Mandela used the trope of the rainbow to underpin the multi-ethnic dimension of South African society. The trope has its roots in the Old Testament, where God gives a rainbow to Noah to symbolize the covenant he makes with his people, and to remind them that there is a future to look forward to. It is also a strong component of the Xhosa culture, where the rainbow stands for bright futures and hope (Baines). Moreover, in Newton's theory, the rainbow has seven colors, most of which are central to Nguni cosmology. In many cultures, the rainbow, as a result, stands as a possible analogue to a symbolic unity, gathering previously separated and fragmentary identities into an inclusive and variable whole. Clive Barnett explains this further in "Broadcasting the Rainbow Nation," an essay focusing on the development of the media landscape in South Africa during the 1990s. During that decade, he argues, mainstream "understandings of culture which privilege[d] ethnicity [were] displaced by understandings of culture as 'arts' and 'popular culture' and of identities as multiple rather than singular" (276).

This paper explores how the concept of the Rainbow Nation has evolved in the past fifteen years, using two different points of view to illustrate these changes. J. M. Coetzee is a white English-speaking writer of Afrikaner descent who has immigrated to Australia. His novel Disgrace, published in 1999 caused a severe outcry, with critics accusing him of pandering to fantasies of a dangerous native male population aggressively intimidating, harassing and harming the innocent white female on the veld. In Disgrace, David Lurie, a Humanities professor, flees Cape Town after losing his position as the result of a sexual scandal. Having found refuge on his daughter Lucy's farm, in the depths of the Eastern Cape, he tries to adapt to her lifestyle while writing his magnum opus, an opera on Byron. After an attack on the farm and Lucy's rape, the relationship between father and daughter, already tenuous, frays when David realizes that their neighbor, Petrus, is harboring one of the criminals. He refuses to understand why Lucy accepts the events as they are, without fighting back, and goes through the process of reassessing

1. In Nguni cosmology, red stands for health, life, death, danger; yellow for fertility; green for new life whereas blue was used to dye the hair and body. (Mabona 268) 
his understanding of life and of the dynamics of South African society while carrying out voluntary work for the local animal shelter. Ten years after publishing Disgrace, Coetzee comes back to South Africa in his short story "Nietverloren,", in which a South African narrator guides a pair of foreign friends through the country, and stops in a small old-fashioned Boer farm called Nietverloren. The story ranges from nostalgia to bitterness, detailing the ways in which South Africa has changed over the last hundred years, and especially since the end of apartheid.

The other author studied in this essay is Achmat Dangor, a Coloured writer living in Johannesburg, who also happens to be serving as chief executive of the Nelson Mandela foundation. In Bitter Fruit, Dangor describes the unraveling of the Ali family, through the resurgence of a secret that tears a hole in the web holding Silas, Lydia, and Mikey together, baring old wounds and new desires. Silas Ali, the father, used to be an activist for the ANC, and his actions indirectly led to the rape of his wife Lydia by a white lieutenant, an event he was forced to witness while trapped in a police car. Mikey/ Michael, the child born to Lydia after the rape, belongs to the golden generation that grew up after apartheid, a generation which should have been free from its parents' mistakes and sorrows. Dangor manages to weave the story of these three characters into the fabric of South African history, situating the birth of the Rainbow Nation within a larger context of betrayal and pain spanning several generations.

These conflicting portraits of today's South Africa reveal the darker aspects of the Rainbow Nation wrestling with questions of Black, White, and Coloured identities, as well as with the difficulty of reconciling the past with the present. These texts of fiction map some of the directions the country and its literature are taking today, wondering to what extent the idea of the Rainbow Nation has survived intact, more than fifteen years after the end of apartheid.

At a roundtable session on the Truth \& Reconciliation Commission held in Toulouse during the 2010 "Marathon des Mots," Dangor claimed that the TRC had further motives than bridging the gap between different factions, or soothing the pains caused by apartheid. One of the main purposes of the TRC in South Africa was to ensure that the subsequent elections would take place in a climate where the police and the army would protect the voters, even if the vote led to the victory of the National Party. As far from the Nuremberg trials as possible, the TRC aimed to offer amnesty for gross violations of human rights with the hope that by lancing the boil, communities would start healing and collaborate in the building of a new form of government. While many of the proceedings and events of the TRC were illustrated in Antje Krog's autobiographical work Country of my Skull, Dangor explained in interview how some of the hearings, "often the sexual abuse ones," were conducted in closed sessions, frequently at the request of the victim (Knecht 1). The Commission brought aggressor and victim face to face in a confrontation that was one of the many "flashes of insights" that struck Dangor, and served as the starting point of his novel. He claims in the same interview that, as he watched the TRC broadcasting, "it was really something that [he] felt needed to be done from a re-imagined point of view" (Knecht 1). The need to rewrite, re-imagine, and retell the story from the inside, led to Bitter Fruit, the title of which metaphorically alludes to rape, incest, murder, and Mikey's birth. As his past comes back to haunt him, the

2. "Nietverloren" is an Afrikaans term which can be translated as "not lost." 
character methodically plans to kill his biological father once he comes to suspect that he might be the son of a white lieutenant, thereby perpetuating the circle of violence, as if the fruit could not fall far from the tree.

In Bitter Fruit, Dangor's use of onomastics highlights the characters' origins as the author opted for names that hark back to the days of settlement and the recreation of history through etymology. The maiden name of Lydia and her sister Gracie is Oliphant, and Gracie's husband Alec is convinced of its Zulu origin:

Gracie was tired of explaining to Alec - and his skeptical Johannesburg township kind

- that the name "Oliphant," sadly, was Scots in origin and not an Anglicization of

"Ndhlovu," the isiZulu word for "elephant" and a common African surname. If it had been, perhaps we would belong! (82)

The desperate need to belong on Gracie's part, her desire to feel anchored in a swiftly tilting society are balanced by Alec's belief that the names of Coloured people are all native, and come from Zulu words. ${ }^{3}$ The friction between "Ndhlovu" (/n'ßzo:vu/) and "Oliphant" (/'כləfənt/), ${ }^{4}$ featuring a similar pattern of consonants, with an approximant followed by a fricative, remains intact, an unresolved tension comparable to the colors in a rainbow, always separate and distinct, never quite merging together. The symbolism underlying Michael's name is also prominent. While he is first presented through his nickname, Mikey reverts back to the original form of his name, Michael, partway through the book. This inversion coincides with his decision to become involved in the local mosque that his grandfather used to lead, as well as the radicalization of his stance against the generation of his parents. His close friend Vinu tells Michael, at one point, that he would be the ideal one to exact retribution on her molesting father: "I could get you to kill him for me. Michael the Avenger. That title suits you" (225), But Michael's new identity as the embodiment of the archangel is negated by his parents. The misnaming of Michael by his mother who persists in calling him Mikey, is akin to that of Michael K. in Coetzee's Life and Times of Michael K: "the misnaming of $\mathrm{K}$ by others throughout $[\ldots]$ takes on significance: once more, his voice is not heard, overridden by the identity others impose on him" (Kossew 147). Dangor leaves the narrative open-ended, but has hinted in interviews that there was a strong possibility that Michael would become a terrorist in the long run (Knecht 5-6). The Alis are Muslim and Coloured, part Indian, part African, and part White too. Like Dangor - who boasts Indian, Malay, and Dutch origins - the identity of the characters is rooted in their ethnic background, which sometimes brings them together, and sometimes forces them apart when misunderstandings and conflicting cultural expectations arise.

While the Coloured population stands at the heart of Bitter Fruit, Coetzee, on the other hand, edges them out of Disgrace. Soraya, the prostitute that David Lurie hires every week at the beginning of the novel, is probably Coloured: he mentions her "honey-brown body, unmarked by the sun" (1). She appears also to be Muslim, since Lurie confesses that "he likes giving her presents. At New Year he gave her an enameled bracelet, at Eid a little malachite heron" (5). These hints are only given in passing, and

3. "isiZulu” refers to the Zulu language in Zulu. Dangor's choice to use "isiZulu” instead of "Zulu” reflects Gracie and Alex's determination to belong, as shown by their insistence on using Zulu phrases whenever apt.

4. One should also note that South Africa has three different Olifants River, two of which are in the Cape area. These rivers might have been a way for Gracie to belong to the country, but their names derive from the Afrikaner term, not the Zulu word. 
Lurie prefers to dwell on the perfect nature of their arrangement rather than on the perfection of Soraya's body. While the first Soraya is described in some detail, the second girl with this nom de commerce only warrants the terms of "unpractised" and "coarse" (8). What Lurie liked in the first Soraya was the exotic whiff she brought to his life, as well as the sense of importance she gave to him, while the younger one's attempts to arouse interest only serve to alienate him further. In the same way, the student he gets involved with, Melanie Isaacs, is described as having "wide, almost Chinese cheek-bones" and, a few lines below, she is described as "Melanie, the dark one" (11), which, admittedly, could also be a pun on the etymology of her name. Just like Michael $\mathrm{K}$ is never formally identified as Coloured by the narrative voice, Coetzee skirts the problematic issue of race in Disgrace, where it is never straightforwardly addressed in terms of Black or White. One of the reasons could be that most of the action takes place in the Eastern Cape, in the countryside, far from the teaming life of the Cape or Johannesburg. Coetzee reportedly claimed that when writing Michael K, he "very consciously" tried to avoid "the over-simplicity of the black/white dichotomy" (Penner 91). Likewise, Disgrace glosses over Melanie's skin color, letting the reader infer she might be Coloured, but never openly stating so. Although they allegedly avoid the dichotomy, Coetzee's early novels nevertheless remain entrenched in often bilateral confrontations: David and Lucy against Petrus in Disgrace and Elizabeth Curren against John and Bheki in Age of Iron. The color bar is still very much in place, contaminating his fiction with oppositions between ethnic groups despite his desire to avoid simplifying a complex situation. This can be seen as a foray into the possibilities of removing oneself - and one's fiction - from the immediate historical context, to explore the possibilities given by this translation into a new narrative space:

Coetzee's allegorical scheme does work to abstract his meditation on forgiveness and victimization from the immediate scene of the TRC, it also arguably replicated the ageold sex-gender for race/nation trope that many feminists of colour have criticized in anti-colonial and anti-racist cultural politics. (McGonegal 210)

This erasure, eviction or omission of a section of the South African population is rooted in the country's past and can be compared to the photographs taken in the nineteenth and early twentieth century that mostly showed the white settlers in an advantageous light, unless they were taken for anthropological purposes. In "Nietverloren," Coetzee describes such a picture, taken to commemorate a hunting outing: "in the background, not supposed to be part of the photograph, were two donkeys yoked together, and a man in tattered clothes, also not supposed to be in the picture" (22). The presence of the man, tacked on to the end of the sentence almost as an afterthought, shows how little the figure mattered in the eyes of its contemporary beholders. It was common practice to obfuscate parts of history or to reinvent them, to forget the times when miscegenation was a crime. The competition between settlers of Dutch origin and those later of English origin is denounced in "Idleness in South Africa," an essay in which Coetzee explains how the idleness of the native populations clashed and came up against the ideology of Boer settlers, who hoped to be themselves idle, and have the native populations toil in their place:

To understand why the Hottentot way of life, characterized by (and stigmatized for) its idleness, was in no way held up to Europe as a model of life in Eden, we must be aware 
of attitudes towards idleness prevailing in Europe at the time when Europe, and particularly Protestant Europe, was colonizing the Cape. (White Writing 20)

The Protestant belief that an idle brain is the devil's workshop was a driving force behind much of the colonization of Southern Africa. The Boers enlisted and enslaved the Khoisan to work for them, forcing them out of the idleness they favored, and on which they thrived, into a life of labor, which turned the Boers into "farmers living in mean dwellings set on vast tracts, barely literate, rudely clad, surrounded by slaves and servants with too little employment" (White Writing 31). Thus the "man in tattered clothes" previously glimpsed in "Nietverloren" is an index of the complexity of the situation in South Africa at the time, a complexity which was suppressed, kept out of sight, and cropped up only inadvertently, in the background of a photograph. Coetzee uses a similar image in Slow Man, where one of the characters, a young teenager of Croatian origin, touches up historical photographs. Obliterating the original, nineteenth-century Australian mining settler families, he inserts the faces of his own family into the picture, thus folding time, and the issue of immigration, on itself. ${ }^{5}$

J. M. Coetzee and Achmat Dangor present two distinct visions of South Africa today: in Coetzee's novel and short story, the only meaningful presences, when they are mentioned without being allegorized, are those of the White and Black population whereas in Dangor's novel, the others, the Coloured, the Métis, the outsiders, those poised at the intersection between languages, cultures and populations, are at the heart of the country. This opposition, this dissimilarity, is reinforced in their respective treatment of rape. Coetzee chooses not to show the rape that Lucy undergoes at the hands of the three attackers; strangers she had initially welcomed into her home, and offered help to. Along with the silence, the lacunary account reminds David and the reader that neither of them was there (Disgrace 140). Dangor, on the other hand, argues that too much has already been hidden, and that his decision to write about rape - to write the rape into the novel - was a deliberate, conscious one, taken after he read the testimonies and transcripts of some of the closed hearings of the TRC after they were inadvertently made accessible online for a very short period of time (Knecht 2). The description of the ordeal Lydia suffers is harsh and unforgiving. It forces the reader to recognize the weight of the characters' and of the country's past. Although the political transition has improved the situation, the issues Dangor deals with are still relevant today. What might have been forgiven, or forgotten can always resurface and haunt the next generation.

The reactions of both women are also very different. Both cloak themselves in silence, Lydia internalizing her pain and anger, while Coetzee's Lucy decides not to retaliate because she believes her rape is part of a natural process. That said, both recoil from the starkly personal dimension the rape takes in their eyes. As Lucy puts it: "it was so personal [...] it was done with such personal hatred. That was what stunned me more than anything" (Disgrace 156). David, on the other hand, takes on a historicist position and argues that it was a form of retribution exacted by the oppressed population, a way

5. Australia's past (and present) is in this novel implicitly used by Coetzee as an analogy to South Africa, since both territories were colonized by white populations who tried to suppress and subjugate the indigenous populations. The parallel between the two settler colonies is taken up in more details in Diary of a Bad Year, where the opinion "On Raiding" focuses on the historical background of apartheid and precedes "On Apology," another opinion piece foreshadowing the apology to Aboriginal Australians made by Prime Minister Kevin Rudd, on behalf of the Australian government, on 13 February 2008. 
of paying for some of what Lucy's ancestors may have done. The act of rape would then be absolutely impersonal, since it would only be inflicted on Lucy inasmuch as she was there and was seen as a representative of the former oppressing class. Yet, to the victim, rape can be nothing but personal, and Dangor's Lydia is bitter, sour, eaten up alive by the anger and the shame that she still feels years after. The silence of both women also stems from the belief that the rape was an individual, private experience, something they simply cannot share with others, even if there might have been others around them at the time. Lydia refuses to bring it up with the TRC, declaring that Archbishop Tutu "will never understand what it's like to be raped, to be mocked while he's being raped, to feel inside him the hot knife [...] turning into a torture instrument" (16).

Both novels use the event to explore how rape tears families apart, and how it sometimes forces them together; how it influences relationships, and how in turn everybody must rethink their stance on the question of the Rainbow Nation, if such a nation could let this kind of crime happen in the first place.

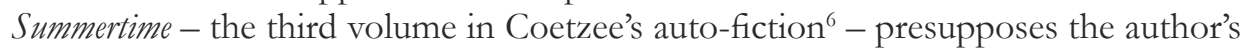
death and a second party's posthumous search for the drive behind Coetzee's writing. The narrator, a young English biographer in charge of the research, interviews one of Coetzee's cousins, Margot. As she reminisces about the time they spent together on the farm in the Karoo, she wonders:

Does he really think of himself as an Afrikaner? She doesn't know many real [egte] Afrikaners who would accept him as one of the tribe... To pass as an Afrikaner nowadays you need at the very least to vote National and attend church on Sundays. She can't imagine her cousin putting on a suit and tie and going off to church. (95)

Margot's comment is supposed to have been uttered in the 1970s. As such, it gives us an insight into Coetzee's understanding of what being a proper Afrikaner might have meant at the time. Margot's amusement is underscored by the expression "at the very least," which mocks the sectarianism of Afrikaners and their rejection of any one who will not abide by their normative definition of an Afrikaner identity, not matter how narrow it may be. The post-apartheid South Africa described in Coetzee's writing is rather bleak: it acknowledges the disenchantment that has eclipsed the hope the Rainbow Nation once aroused with its project of embracing the various communities constitutive of the nation. Instead of bringing them together like the colors of the rainbow, the country is fracturing along multiple lines of division, gaps widening between families, neighbors, and communities:

Hunting and gathering, then pastoralism, then agriculture: those, he had been taught as a child, were the three stages in the ascent of man from savagery... Who would have believed that there were places in the world where in the space of a century or two man would graduate from stage one to stage two to stage three and then regress to stage two. ("Nietverloren" 24)

While Disgrace contains several indications that all is not well in the new Rainbow Nation, "Nietverloren" - meaning literally "not-lost," and therefore "still-there" - sug-

6. The generic underpinnings of Coetzee's autobiography changed in Summertime. While Boyhood and Youth could both qualify as (incomplete) autobiographies, the third volume features a researcher investigating J. M Coetzee's past after his death, which resolutely reorients the trilogy towards autofiction or "autre-biography". Coetzee's conception of "autre-biography" is presented in his interview with David Attwell (Doubling the Point 391-6). Attwell subsequently reused the term, when he entitled the 2002 interview he conducted with Coetzee: "All Autobiography is Autre-biography" (Selves in Question 213). 
gests that the present situation stems from a betrayal of what South Africa used to be, or could have been, for the benefit of cheap money and the "safari experience" (26). The three stages of man - hunting / gathering, pastoralism and agriculture - are opposed to today's state of affairs when hunting has taken over as a prime sport, whereas pastoralism and agriculture have been given up, because they make "no economic sense" (26). In the same way, Lucy's farm has evolved: "In the old days, cattle and maize. Today, dogs and daffodils" (Disgrace 62). The country has advanced and improved, leaving behind traditional farming. Yet Coetzee sees this change as a form of betrayal, since the new farms are no more sustainable than the old ones: Lucy's kennels are at the mercy of a raid, while the Nietverloren farm thrives on the tourists' nostalgia for a glorified past. The name of the farm symbolizes the lie that the older generation might tell itself to keep going. As apartheid and inequality shaped the country in the past three hundred years, the scars and memories they have left will go on shaping the country for many more. The image of flailing and threshing taken up in "Nietverloren" used to refer to the productive activity that ensured the fertility of the following year's crop since it separated the grain from the chaff (22). But the more contemporary version of thrashing and flaying has become sterile, tainted with shame and disgrace, as the South African populations of various descents cannot help but feel guilty over events they might not have any hand in, or influence on.

Dangor's characters, however, do not abandon all hope, and press on trying to solve their issues. Silas is actually portrayed as a prominent spin-doctor in the new regime, ensuring the transition between the first and the second president since the end of apartheid. He is at the heart of things, and has been told the good and the bad, has been asked time and again to convince the population to trust him, to trust the government, to know better and work for the people. His position as an insider, a sometimes professional liar, makes him the necessary pivot from which to observe the story's many different angles. From Lydia to Michael to Gracie and Alec, Dangor uses Silas as the prism through which all passes. It creates the feeling that the gaps between family members and parts of society would be bridged, if South Africans could try hard enough, believe in the promise of the rainbow and struggle to maintain the cohesion of the nation while acknowledging their differences and divergences. This hope is fragile though, confronted as it is with the issue of misunderstandings, misperceptions, hasty conclusions. In the opening chapter, originally published as a stand-alone short story, Silas and Lydia fight after he tells her he came across François Du Boise, her aggressor, and she accuses him of not understanding her pain, a recrimination which he refuses to acknowledge:

Silas grabbed Lydia by the arms and shook her. The glass of beer fell from her hands. She kissed him on the mouth, held him close to her, and sucked his tongue into her mouth the way she did when she was really passionate. She tasted of hops, of bitter fruit. She gasped, then leaned up against him, her head against his chest, weeping, making gentle dancing movements with her feet. He cradled her head, astonished by how much taller he was. He glanced down the slenderness of her back, saw the slow pool of blood spreading on the floor, saw his heavy shoes immersed in its dark glow, saw her feet dancing, delicate little steps, on the jagged edges of the broken beer glass. (17)

In this passage, Dangor opposes Lydia's actions to Silas's perception of them: the first sentences have her kissing him, holding him, weeping and dancing, while he then goes on to cradle her, looks at her feet and notices the broken beer glass. Her active state is opposed to his passive attitude, reminding the reader that she was the one who was 
raped, while he watched, unable to act. Yet the earlier accusation Lydia made, arguing that Silas would never be able to grasp what she underwent although he was there, is brought into relief in this passage, where he is convinced that she is dancing, passionate, and confused. The "gentle dancing movements with her feet," taken up subsequently with "her feet dancing, delicate little steps" are opposed to the "jagged edges of the broken beer glass" which he has not noticed at first. "Bitter fruit" echoes the title of the novel but it also refers to the beer that Lydia has just drunk and that stands as a symbol of manhood, for earlier on she told Silas that she "want[ed] to taste like a man, all sour" (16). Drinking beer and speaking like a man, Lydia is actually speaking "within a masculine discourse, claiming that she became her rapist's 'property' and that Silas was 'honour'-bound to revenge this assault" (Samuelson 2). Although they stand together as husband and wife, they are separated by an event they have both avoided talking about for years, because it might have shown them how little they knew, and accepted, of each other. The tenderness of the moment is somehow at odds with their mutual incomprehension, staking the claim that love might or might not be enough to bring and keep two people together.

In To the Lighthouse, Mrs. Ramsey describes humankind's mortality by saying "it was all as ephemeral as a rainbow" (Woolf 23). The rainbow is a delicate balance of rain and light reflecting and fragmenting into many colors. Yet as Mrs. Ramsey reminds us, it is of transient nature, and the conditions for its existence are seldom met. The enthusiasm felt in 1994 at the fall of the apartheid regime has been dampened by the economic and racial issues that have cropped up and resurfaced since. Although the future of the country still looks bright, especially since it is a global economic player, the subjacent turmoil makes for an uncertain and fragile present. Similarly, the mutability of South African society, the changes remolding it find their way into its literature. Although Coetzee probably wrote "Nietverloren" from abroad," its setting is definitely South African. The story exudes nostalgia, as evinced by the opening which muses over the mysterious origin of the circles of bare earth found in the Karoo: "he thought of it as a fairy circle, a circle where fairies came at night to dance by the light of the tiny sparkling rods that they carried in the picturebooks he read" (21). The ending of the short story, however, rings a pessimistic note. With the "bitterness of defeated love," the narrator asserts that "a light grade of sorriness sits over the whole country, like cloud, like mist. But there is nothing to be done about it, nothing he can think of" (27).

Contemporary South African writers propose strikingly different mappings of their country, depending on their individual experience, stance, and point of view. Whereas some, like Coetzee, decide that what is left is "to be waiters and whores to the rest of the world" ("Nietverloren" 27), and ultimately distance themselves, literally and fictionally, from the country, Dangor has a much more positive vision. The ambiguous citation of Leonard Cohen's song Last Year's Man at the end of Bitter Fruit, ${ }^{8}$ provides the reader with an interpretive key to the novel:

7. The first occurrence of this text I have found was given at a reading, for College Civitas on 8 June 2006.

8. Although Bitter Fruit refers to Michael's conception, the title also echoes the title of the song Allan Lewis composed for jazz singer Billie Holiday. The events described in "Strange Fruit" refer to segregation and the lynching of African Americans, but to many they will also evoke the violence of apartheid: "Southern trees bear a strange fruit/ Blood on the leaves and blood at the roots/ Black bodies swinging in the breeze." 
But the skylight is like skin for a drum I'll never mend And all the rain falls down, amen

On the works of last year's man. (281, italics in the original)

Dangor and other South African writers claim for themselves the metaphor of past and future, from last year's labor to tomorrow's crops. André Brink summarizes their feeling of excitement:

Much of [today's South African literature] is exhilarating, often tremendously relevant and significant, reflecting the profound joy that resides in the rediscovery of literature, not just as an account or a reflection, but as an adventure and as an affirmation of the indomitable energy of the human spirit. Bliss it is in this dawn to be alive. (19)

With Lydia's concluding words, Dangor echoes Brink's lines and the sentiment that hope endures despite hardships, overwhelming tragedies and sacrifices:

Carry your own burdens,

Mister my friends...

Amen, Amen. (281, italics in the original)

Madeleine LAURENCIN

University Paris 3 - Sorbonne-Nouvelle

\section{Works Cited}

Atтwell, David. Doubling the Point: Essays and Interviews. Cambridge: Harvard UP. 1992.

—. "All Autobiography is Autre-biography." Selves in Question: Interviews on Southern African Auto/ biography. Ed. Judith Lütge Coullie, Stephan Meyer, Thengani Ngwenya and Thomas Olver. Honolulu: U of Hawai'i P, 2006. 213-8.

BAINES, Gary. "The Rainbow Nation? Identity and nation building in post-apartheid South Africa." Mots Pluriels 7, 1998. 5 June 2011 < http://www.arts.uwa.edu.au/MotsPluriels/MP798gb.html >.

BarnetT, Clive. "Broadcasting the Rainbow Nation: Media, Democracy, and Nation-Building in South Africa." Antipode 31.3 (1999): 274-303.

Brink, André. "Post Apartheid Literature: A Personal View." J. M. Coetzee in Context and Theory. Ed. Elleke Boehmer, Robert Eaglestone and Katy Iddiols. London: Continuum, 2009. 11-19.

Coetzee, J. M. White Writing: On the Culture of Letters in South Africa, 1988. Braamfontein: Pentz, 2007.

-. Age of Iron, 1990. New York: Penguin, 1998.

—. Boyhood: Scenes from provincial life, 1997. London: Vintage, 1998.

—. Disgrace. 1999. London: Vintage, 2000.

-. Youth, 2002. London: Vintage, 2003.

-. Slow Man, 2006. London: Vintage, 2007.

—. Diary of a Bad Year, 2007. London: Vintage, 2008.

- " "Nietverloren." Ten Years of the Caine Prize for African Writing. Oxford: New Internationalist, 2009. 21-8.

—.Summertime. London: Harvill Secker, 2009.

CoHen, Leonard. "Last Year's Man." Songs of Love and Hate. Sony Music Entertainment, 1971.

Dangor, Achmat. Bitter Fruit. 2001. London: Grove Atlantic, 2004.

Holiday, Billie, perf. "Strange Fruit." Lyrics by Lewis Allan. The Billie Holiday Songbook. Polygram Records, 1986.

KNECHT, Stacey. "Interview Achmat Dangor." The Ledge (March 2005): 5 June $2011<$ http:/ /www.theledge.com/flash/ledge.php?conversation $=57 \&$ lan $=\mathrm{UK}>$.

Kossew, Sue. Pen and Power. Amsterdam: Rodopi, 1996.

KROG, Antje. Country of my Skull. 1998. London: Random, 1999.

Mabona, Mongameli. Diviners and Prophets among the Xhosa (1593-1856). Münster: Lit Verlag, 2004.

Mandela, Nelson. "Inaugural Speech.” U of Pennsylvania - African Studies Center. 5 June 2011 $<$ http://www.africa.upenn.edu/Articles_Gen/Inaugural_Speech_17984.html>. 


\section{commonweatTH Essays and stunies}

McGonegal, Julie. Imagining Justice: The Politics of Postcolonial Forgiveness and Reconciliation. Montreal: McGill-Queen's UP, 2009.

Penner, Dick. Countries of the Mind: The Fiction of J. M. Coetzee. New York: Greenwood, 1989.

SAMuelson, Meg. "Speaking rape 'like a man': Achmat Dangor's Bitter Fruit." Annual Review of Islam in South Africa 7 (2004): 11-4.

Woolf, Virginia. To the Lighthouse. 1927. London: Collector's Library, 2004. 